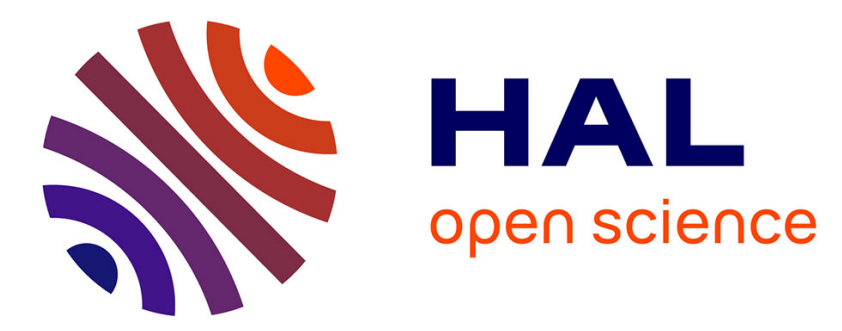

\title{
Effects of various rootstocks on xylem exudates cytokinin content, nutrient uptake and growth patterns of grapevine Vitis vinifera L. cv. Thompson seedless
}

Nikolaos Nikolaou, Magdalini Koukourikou, Nikitas Karagiannidis

\section{- To cite this version:}

Nikolaos Nikolaou, Magdalini Koukourikou, Nikitas Karagiannidis. Effects of various rootstocks on xylem exudates cytokinin content, nutrient uptake and growth patterns of grapevine Vitis vinifera L. cv. Thompson seedless. Agronomie, 2000, 20 (4), pp.363-373. 10.1051/agro:2000133 . hal-00886052

\section{HAL Id: hal-00886052 \\ https://hal.science/hal-00886052}

Submitted on 1 Jan 2000

HAL is a multi-disciplinary open access archive for the deposit and dissemination of scientific research documents, whether they are published or not. The documents may come from teaching and research institutions in France or abroad, or from public or private research centers.
L'archive ouverte pluridisciplinaire HAL, est destinée au dépôt et à la diffusion de documents scientifiques de niveau recherche, publiés ou non, émanant des établissements d'enseignement et de recherche français ou étrangers, des laboratoires publics ou privés. 


\title{
Effects of various rootstocks on xylem exudates cytokinin content, nutrient uptake and growth patterns of grapevine Vitis vinifera L. cv. Thompson seedless
}

\author{
Nikolaos NiKOLAOU ${ }^{\mathrm{a} *}$, Magdalini A. KouKOURIKOU ${ }^{\mathrm{a}}$, Nikitas KARAGIANNIDIS ${ }^{\mathrm{b}}$ \\ a Aristotelian University of Thessaloniki, Department of Agriculture, 54006 Thessaloniki, Greece \\ ${ }^{\mathrm{b}}$ National Agricultural Research Foundation, Soil Scinence Institute of Thessaloniki, 57001 Thermi Thessaloniki, Greece
}

(Received 13 July 1999; revised 31 January 2000; accepted 28 March 2000)

\begin{abstract}
Variations in cytokinins, mineral nutrient elements of xylem exudates collected before bud burst, petiole and blade nutrient concentration at veraison, and shoot growth patterns were studied as affected by the rootstock. A two year experiment was conducted on field grown grapevines cv. Thompson seedless, grafted onto 420AMgt, 110Richter, 99Richter, 41BMgt, Kober 5BB, 8B Teleki, 1103 Paulsen, 31 Richter and 3309C rootstocks. Xylem exudate cytokinins were positively correlated with relative bud burst number, shoot elongation in the early season, and shoot elongation at veraison stage. A strong positive relationship between cytokinin content and total nitrogen was also found. The rootstocks 420AMgt, 110Richter, and 99Richter, which showed high levels in cytokinin content also had high nitrogen levels in xylem exudates and leaf blade. Multivariate Analysis allowed to show that rootstocks with similar levels in cytokinin concentrations in xylem exudates, also presented a closely similar behaviour in nutrient uptake.
\end{abstract}

Grapevine / rootstock / xylem sap / cytokinin / mineral uptake

Résumé - Étude de l'effet de différents porte-greffes sur la concentration en cytokinines dans les pleurs du bois, l'absorption minérale et les caractéristiques de croissance de la vigne Vitis vinifera cv. Sultanine. Les variations de la teneur en cytokinines et en éléments minéraux des exudats du xylème récoltés avant le débourrement, de la compositions minérale du limbe et du pétiole à la véraison, et de la croissance des rameaux ont été étudiées en fonction du porte-greffe. Les essais ont été réalisés au champ sur la variété Sultanine greffée sur les porte-greffes 420A Mgt, 110Richter, 41B Mgt, Kober 5BB, Teleki 8B, 1103 Paulsen, 31Richter, et 3309 Couderc. La concentration en cytokinines dans les exudats du xylème a été positivement corrélée avec le nombre relatif de bourgeons débourrés et avec l'allongement des rameaux au début de la période végétative et à la véraison. Une corrélation élevée entre la concentration en cytokinines et la teneur en azote totale a également été mise en évidence. Les porte-greffe 420A Mgt,

Communicated by Gérard Guyot (Avignon, France)

* Correspondence and reprints

nicolaou@ agro.auth.gr 
110Richter et 99Richter ont présenté les teneurs en cytokinines les plus élévées et également une forte teneur en azote totale. Des analyses multifactorielles ont permis de montrer que les porte-greffes caractérisés par des concentrations proches en cytokinines ont présenté une composition minérale voisine.

\section{Vigne / porte-greffe / pleurs du bois / cytokinine / absorption minérale}

\section{Introduction}

The xylem bleeding sap of the pruning cuts in a grapevine plant is consistent with a phenomenon indicating an elevated root activity in early spring, just before budbreak and leaf development. The sap exudation from injured overground parts is common in several plant species based on different causes. In grapevine, as the roots warm up in early spring, they absorb nutrient mineral elements [20]. The accumulation of salts in the xylem sap lowers the osmotic potential and consequently the water potential below the water potential of the soil. The inward diffusion of water produces the "root pressure" that is responsible for bleeding in grapevine.

As leaves develop the increasing transpiration produces a negative pressure (tension) in the xylem sap and sap-bleeding ceases. There are many reports about the xylem sap exudate composition of the woody plants. Bollard [9] pointed out that the xylem exudate contains inorganic elements, organic nitrogen compounds, cytokinins and gibberellins and it plays an important role in the translocation of these substances. Other workers reported that the bleeding sap of the grapevine contains sugar, organic acids, amino acids, amides, and nutrient elements [46, 27, 4, 5, 34] as well as cytokinins [28, 47] and gibberellins [40]. Cytokinins are plant growth regulators that influence several fundamental processes of plant growth and development, including cell division and organogenesis. They are predominantly rootborn phytohormones distributed in the shoots via the xylem stream. According to Short and Torrey [37], roots are the main site of cytokinin biosynthesis. It is well known that cytokinins retard proteolysis and chlorophyll degradation during leaf senescence in higher plants [8,35]. According to Badenochjones et al. [7], cytokinins coming from the roots delay leaf senescence and play an important role in regulating transpiration in vivo. Environmental factors such as the mineral nutrient supply affect the plant hormonal balance which regulates growth [3]. It has been shown that the form and concentration of nitrogen sources have an important influence on cytokinins [25].

It has been reported that grapevine rootstock variety has a considerable influence on some plant physiological and production parameters. Plant water status and productivity as well as berry composition, are considerably affected by rootstock $[30,1]$. Studies of root distribution in the soil have shown that rootstock affects both total root number and the size of the smallest roots [26]. Mineral uptake, root density in the soil as well as water relations, are also affected by rootstock $[17,38]$. The purpose of this research was to determine: 1) whether or not rootstock cultivar affect the cytokinins and nutrient element concentrations of the xylem exudate, and 2) whether the cytokinin concentrations are correlated with nutrient uptake and some important growth parameters. Such comparisons should help to clarify the effects of some important grapevine rootstocks on growth and crop patterns of the scion.

\section{Materials and methods}

\subsection{Plant material}

The investigation was conducted at the experimental farm of the Aristotelian University of Thessaloniki during the period of 1997-1998 to compare the effects of some rootstocks on the xylem exudate, cytokinin and inorganic element concentrations of the Thompson seedless variety. 
The experimental plants were fifteen years old, grown in fields and grafted onto nine different rootstocks. The rootstocks used in the trial were 420AMgt, 5BBKober, 8BTeleki (V. riparia X V. berlandieri), 110Richter, 1103Paulsen, 99Richter (V. rupestris X V. berlandieri ), 41BMgt (V.vinifera $\mathrm{X}$ V.berlandieri), 3309Couderc (V. riparia $\mathrm{X}$ $V$. rupestris) and 31Richter [Vitis berlandieri $\mathrm{X}$ Solonis ( $V$. riparia $\times V$. rupestris $\times V$. candicans)]. Vines were unirrigated, bilateral cordon trained, pruned to 8 canes of 10 nodes ( 80 buds per plant) and spaced $2.0 \times 1.6 \mathrm{~m}$. Five replications of each rootstock with one plant per experimental unit were used in randomized blocks down a single row. The soil of the experimental vineyard was sandy loam in texture, with low organic matter $(1.36 \%)$, pH 7.2, low content in total $\mathrm{CaCO}_{3}$ $(1.8 \%)$ and $\mathrm{P}\left(7.8 \mu \mathrm{g} \cdot \mathrm{g}^{-1}\right)$. Mean temperature and precipitation in March were $7.0{ }^{\circ} \mathrm{C}$ and $23.5 \mathrm{~mm}$ for 1997 and $7.7^{\circ} \mathrm{C}$ and $10.8 \mathrm{~mm}$ for 1988 , respectively. A segment of one $\mathrm{cm}$ was cut from the top of each pruned cane to encourage sap-discharge. The xylem exudates were collected at the begining of phase B (cotton bud) about one week before the bud burst by securing four $0.25 \mathrm{~L}$ plastic bags per plant (two on each arm) at the end of the pruned canes. The tops of the pruned canes were cut at the same time and the bleeding sap was collected over a period of 24 hours for all the rootstocks. The plastic bags were covered with aluminium foil to protect cytokinins from solar radiation. The volume of each collection was measured and then mixed for each plant. One sample of this mixture was used for cytokinin analysis. Ethanol was added to the samples to control growth of microorganisms. Immediately after collecting, the sap was frozen in liquid $\mathrm{N}$ and the samples were transferred to the laboratory, and stored at $-20{ }^{\circ} \mathrm{C}$ for cytokinins and inogranic element analysis.

\subsection{Cytokinin analysis}

The frozen samples were thawed and ethanol was removed at $40^{\circ} \mathrm{C}$ "in vacuo". Ten $\mathrm{ml}$ sub-samples were freeze-dried, redissolved in $80 \%$ ethanol extracted overnight (at room temperature) and centrifuged for $10 \mathrm{~min}$ in a clinical centrifuge
$(4.000 \mathrm{~g})$. The supernatant was dried and analyzed for cytokinins by using Fletcher's and McCullagh's cucumber cotyledon greening assay [14]. Cucumber (Cucumis sativus L.) seeds were germinated in the dark at $28{ }^{\circ} \mathrm{C}$ for 6 days. The cotyledons were excised in dim green light and placed in $5 \mathrm{~cm}$ Petri dishes containing $3 \mathrm{ml}$ of samples or cytokinin solutions ranging from 0.001 to $10 \mathrm{mg} / \mathrm{L}$ $(0.001,0.01,0.1,1,10)$. The dishes were returned to the dark at $28^{\circ} \mathrm{C}$ for $14 \mathrm{~h}$ and then transferred to fluorescent light with an intensity of $0.87 \mathrm{~W} \cdot \mathrm{m}^{-2}$. After $3 \mathrm{~h}$ the chlorophyll from 10 cotyledons was extracted with cold acetone, brought to a volume of $10 \mathrm{ml}$, and their absorbance was measured at $665 \mathrm{~nm}$. A curve was plotted every time with the chlorophyll values derived of known cytokinin concentrations for determination of sample cytokinin quantities.

\subsection{Leaf and bleeding sap nutrient element analysis}

Leaf samples were collected from the base of the shoots (opposite to the first cluster) at the veraison stage. The leaves were separated into blades and petioles, cleaned to remove dust and pesticide residues, dried at $70{ }^{\circ} \mathrm{C}$, ground and passed through a 40 - mesh sieve. One gram of dry matter was ashed at $550{ }^{\circ} \mathrm{C}$, dissolved in $6 \mathrm{~N} \mathrm{HCl}$ and diluted with distilled water. $\mathrm{P}$ was determined spectrometricaly, K with a flame photometer [18], $\mathrm{Ca}$ and $\mathrm{Mg}$ volumetrically with $0.001 \mathrm{~N}$ EDTA [19], $\mathrm{B}$ by the curcumin method and $\mathrm{Mn}, \mathrm{Cu}, \mathrm{Fe}$, and $\mathrm{Zn}$ by absorption spectroscopy. Total nitrogen was determined by the Kjeldahl method [19].

\subsection{Growth parameters}

The elongation of ten shoots per vine was recorded once a week from May to July, when elongation growth ceased. The growth rate (G.R. cm.day ${ }^{-1}$ ) was calculated, when the shoots had ten leaves, and one week before the veraison stage (onset of maturity) since shoot growth cession occurred (G.R.V mm·day ${ }^{-1}$ ). For calculation of growth rate the shoot elongation was calculated 
in one week. Relative bud burst (R.Bb.N.) was calculated as a ratio between the number of buds burst and the total number of buds left at pruning time.

Crop yield was recorded at harvest, and samples of 100 berries per vine were randomly collected, then analyzed for soluble solids and titratable acidity. Soluble solids were measured as ${ }^{0}$ Brix using a hand-held refractometer. Titratable acidity was measured by adding $0.1 \mathrm{~N} \mathrm{NaOH}$ to $10 \mathrm{ml}$ of juice to an end point of $\mathrm{pH} 8.2$.

Pruning weight and mean length of the ten first internodes were recorded after leaf fall and the relative number of lateral shoots (R.L.N.) was calculated by dividing the number of lateral shoots by the number of nodes per cane.

\subsection{Statistical analysis}

Data were analyzed using the SPSS version 8 for Windows programme. The relationship between the cytokinins content in xylem exudates and various growth aspects were tested by Linear regression analysis. The effect of rootstock on exudate cytokinins and mineral content was evaluated by ANOVA. Principal Component (P.C.) and Hierarchical Cluster (H.C.) analysis were used to evaluate the rootstock behaviour in mineral uptake in relation to the exudate cytokinin content.

\section{Results}

\subsection{Cytokinin content}

Differences in xylem exudate cytokinin content were found among the rootstocks used in this study (Fig. 1). Compared to the other rootstocks, 420A showed the highest cytokinin concentration. The rootstocks 110R, 1103P, 99R, 5BB and 8B as well as the $41 \mathrm{~B}$ and $31 \mathrm{R}$ showed intermediate concentrations. The 3309C had significantly lower amounts, when compared with 420A, 99R and $110 R$. No significant differences were found among the 41B, 31R, 5BB, 8B and 1103P.

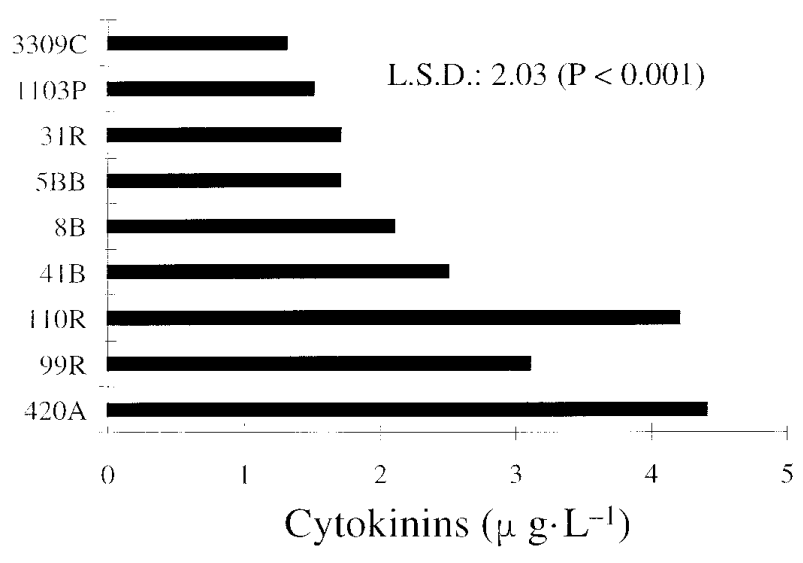

Figure 1. Exudate cytokinin concentration of Thompson seedless grapevine variety grafted onto different rootstocks, in $\mu \mathrm{g} \cdot \mathrm{L}^{-1}$ Zeatine equivalent.

The collected volume of bleeding sap was rated between 98 and $285 \mathrm{ml}$ per plant and per day. Differences between rootstocks were found in collected exudate volume one week before bud burst. It was found that rootstocks with high levels of cytokinin content also had high bleeding sap flow rate (data not shown). Comparing the cytokinin concentrations with the bleeding volume a low but positive correlation was found $\left(\mathrm{r}^{2}=0.51\right.$, $\mathrm{P}<0.001)$.

\subsection{Cytokinins and nutrient elements relationship}

Multivariate analysis (Principal Component analysis and Cluster analysis) were performed using 28 initial variables concerning the xylem exudate cytokinins and nutrient elements and leaf petiole nutrient elements.

Comparing the sap cytokinin content with the xylem exudate nutrient elements, as well as with the leaf nutrient elements, it is interesting to note that there was no significant relationship with most of the nutrients. On the contrary, a significant correlation was found between cytokinin content and total nitrogen (Fig. 2) in xylem exudate as well as between cytokinin content and blade nitrogen (Fig. 3). In regards to the other nutrient elements, very low correlation coefficients between 


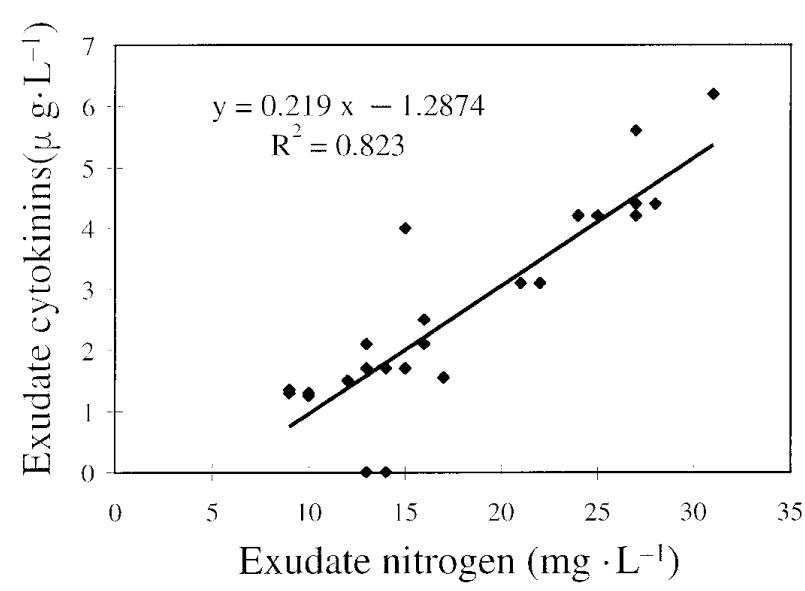

Figure 2. Regression line for exudate cytokinins and total nitrogen content in Thompson seedless variety.

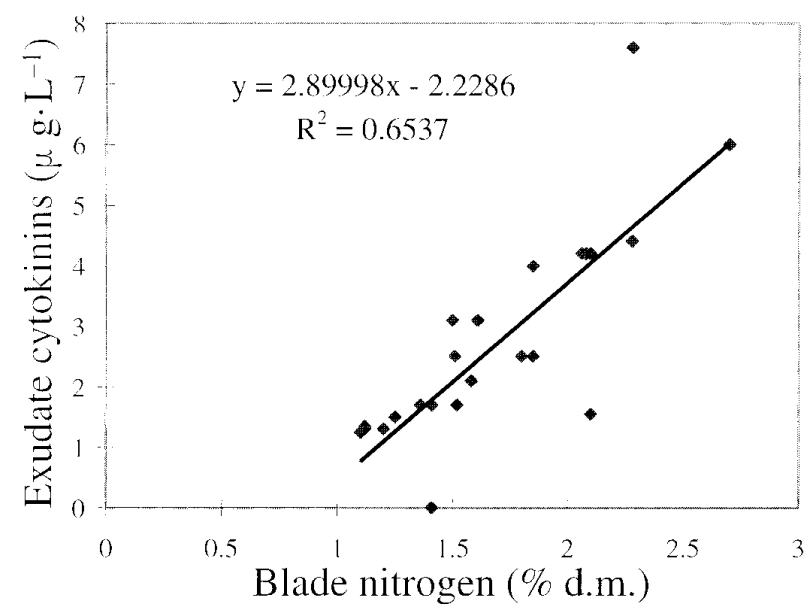

Figure 3. Regression line for exudate cytokinins and blade nitrogen contents in Thompson seedless variety (d.m: dry matter).

cytokinins and leaf nutrient elements were found. A significant correlation was detected between blade and petiole nutrient concentrations for most of the nutrients (data not shown).

Grapevine rootstocks have been grouped into three clusters by cluster analysis application. In the dendrogram supplied by the analysis, the distance (di) of successive clustering is presented on a scale 1-25 (dendrogram not shown). The first one includes 420A, 110R and 99R rootstocks, which showed high exudate cytokinin levels. In this cluster, 1103P which showed intermediate cytokinin levels, is also involved. The second cluster includes 41B, with intermediate sap cytokinin levels and the rest of the rootstocks with intermediate and low levels. The rescaled distance between the first and the second cluster is rated between 10 and 15 . The second cluster is well separated into two subclusters, the first containing rootstocks 41B and $8 \mathrm{~B}$, and the second $5 \mathrm{BB}, 3309 \mathrm{C}$, and $31 \mathrm{R}$. The distance between these two subclusters is rated between 5 and 10. Although no significant correlation was found between sap cytokinins and nutrient

Table I. Mean values of xylem exudate and leaf nutrient elements in Thompson seedless grapevine variety grafted onto different rootstocks.

\begin{tabular}{|c|c|c|c|c|}
\hline $\begin{array}{l}\text { Nutrient } \\
\text { elements }\end{array}$ & $\begin{array}{c}\text { Cluster } \\
1\end{array}$ & $\begin{array}{c}\text { Cluster } \\
2\end{array}$ & $\begin{array}{c}\text { Cluster } \\
3\end{array}$ & $\underset{* *}{\text { L.S.D. }}$ \\
\hline Ex.-Ca meq/L & 6.58 & 4.43 & 4.23 & 1.81 \\
\hline Blade-Ca\%d.m. & 2.63 & 2.00 & 2.11 & 0.65 \\
\hline Petiole-Ca\%d.m. & 2.30 & 2.00 & 1.99 & NS \\
\hline Ex.-Mg meq/L & 3.16 & 4.80 & 4.36 & 0.83 \\
\hline Blade-Mg\%d.m. & 0.53 & 0.55 & 1.46 & 0.56 \\
\hline Petiole-Mg\%d.m. & 0.92 & 0.55 & 0.45 & 0.46 \\
\hline Ex.-N mg/L & 24.50 & 15.80 & 13.10 & 2.11 \\
\hline Blade-N\%d.m. & 2.28 & 1.85 & 1.61 & 0.61 \\
\hline Petiole-N\%d.m. & 0.82 & 0.78 & 0.71 & N.S. \\
\hline Ex.-K meq/L & 1.94 & 3.12 & 3.76 & 0.96 \\
\hline Blade-K\%d.m. & 1.18 & 0.83 & 2.07 & 0.65 \\
\hline Petiole-K\%d.m. & 2.53 & 0.83 & 0.91 & 0.73 \\
\hline Ex.-P meq/L & 2.96 & 16.25 & 7.16 & 2.32 \\
\hline Blade-P\%d.m. & 0.52 & 0.14 & 0.31 & N.S. \\
\hline Petiole-P\%d.m. & 0.30 & 0.14 & 0.18 & N.S. \\
\hline Ex.-Mn ppm & 0.58 & 1.32 & 1.49 & 0.65 \\
\hline Blade-Mn ppm & 74.42 & 122.5 & 67.87 & 11.66 \\
\hline Petiole-Mn ppm & 81.50 & 148.00 & 69.25 & 10.30 \\
\hline Ex.-Zn ppm & 0.62 & 0.82 & 1.25 & N.S. \\
\hline Blade-Zn ppm & 61.50 & 12.50 & 32.00 & 8.13 \\
\hline Petiole-Zn ppm & 72.50 & 12.56 & 16.14 & 5.71 \\
\hline Ex.-Fe ppm & 0.9 & 0.72 & $1.00 \uparrow$ & 0.29 \\
\hline Blade-Fe ppm & 123.25 & 124.50 & 45.00 & 8.52 \\
\hline Petiole-Fe ppm & 62.25 & 71.50 & 23.75 & 7.74 \\
\hline Ex.-Cu ppm & 0.70 & 0.26 & 0.56 & 0.44 \\
\hline Blade-Cu ppm & 13.75 & 10.50 & 14.07 & 2.31 \\
\hline Petiole-Cu ppm & 14.15 & 12.50 & 10.5 & 1.50 \\
\hline
\end{tabular}

*Cluster 1: 420A, 110R, 1103P, 99R

Cluster 2: 41B, Teleki 8B

Cluster 3: 5BB,3309C,31R N.S.: no significant differences Ex : exudate L.S.D.: least significant differences. 
concentrations, using the multivariate analysis it was detected that $420 \mathrm{~A}, 99 \mathrm{R}$ and $110 \mathrm{R}$ rootstocks included in the first cluster with high levels of sap cytokinins, showed high levels of exudate-N, petiole- $\mathrm{Mg}$, blade-Ca, blade and petiole- $\mathrm{K}$, petiole- $\mathrm{Zn}$, too (Tab. I). The rootstocks $41 \mathrm{~B}$ and $8 \mathrm{~B}$ included in a separate cluster showed higher concentrations in petiole and blade-Fe, petiole and blade-Mn and exudate P. These rootstocks had also higher concentrations in exudate $\mathrm{K}$ and $\mathrm{Mg}$ compared to the rootstocks included in the first cluster (420A, 110R,1103P and 99R).

\subsection{Growth as affected by different rootstocks}

The effect of rootstock on the growth pattern of the Thompson seedless variety is presented in Table II. Relative bud burst number was higher in the 110R rootstock. The rootstocks 420A, 99R, and $8 \mathrm{~B}$ also showed a high relative bud burst, without significant differences between them. These rootstocks also had higher growth rate (G.R.) at the stage when the shoots hade ten leaves and at the veraison stage, whereas the 3309C, 31R, and 1103P showed the lowest rates. No signicant differences were found in relative lateral shoot number (R.L.N.) among the rootstocks.
Table III. Effect of rootstock on mean vine yield and berry composition of Thompson seedless grapevine variety.

\begin{tabular}{lccc}
\hline Rootstock & $\begin{array}{c}\text { yield per vine } \\
(\mathrm{kg})\end{array}$ & Brix $^{0}$ & $\begin{array}{c}\text { T.A. } \\
\left(\mathrm{g} \cdot \mathrm{L}^{-1} \text { tart.acid }\right)\end{array}$ \\
\hline 420A & 6.50 & 21.5 & 4.5 \\
99R & 5.80 & 22.0 & 4.2 \\
110R & 6.40 & 20.8 & 4.7 \\
41B & 7.60 & 19.7 & 4.3 \\
8B & 5.50 & 22.0 & 4.2 \\
5BB & 6.50 & 21.4 & 4.8 \\
31R & 5.40 & 22.2 & 4.0 \\
1103P & 4.30 & 23.1 & 3.8 \\
3309C & 3.60 & 22.0 & 3.8 \\
L.S.D. & & & \\
(P<0.001) & 0.53 & 0.46 & 0.28 \\
\hline
\end{tabular}

L.S.D.: least significant differences.

Results for yield per vine and berry composition are given in Table III. Mean yields per vine of 41B, $5 \mathrm{BB}$, and $110 \mathrm{R}$ were significantly higher than those found in the other rootstocks. Elevated yield per vine achieved by these rootstocks had a restricted effect on berry soluble solids. However, the fruit in all of the cases had a very satisfactory sugar content.

Table II. Effect of rootstock on some growth parameters of Thompson seedless grapevine variety.

\begin{tabular}{lcccccc}
\hline Rootstock & R.Bb.N. & $\begin{array}{c}\text { G.R. } \\
\text { cm/day }\end{array}$ & $\begin{array}{c}\text { G.R.V. } \\
\text { cm/day }\end{array}$ & $\begin{array}{c}\text { P.W. } \\
\text { kg/vine }\end{array}$ & $\begin{array}{c}\text { M.I.L } \\
\mathrm{cm}\end{array}$ & R.L.N. \\
\hline 420A & 0.59 & 5.87 & 0.58 & 1.95 & 5.80 & 0.31 \\
99R & 0.57 & 6.21 & 0.44 & 2.35 & 5.65 & 0.35 \\
110R & 0.61 & 6.32 & 0.53 & 2.11 & 5.05 & 0.36 \\
41B & 0.47 & 4.05 & 0.32 & 2.62 & 5.68 & 0.32 \\
8B & 0.56 & 5.02 & 0.25 & 2.23 & 5.82 & 0.25 \\
5BB & 0.51 & 3.90 & 0.24 & 1.42 & 5.90 & 0.31 \\
31R & 0.46 & 3.20 & 0.18 & 1.45 & 5.46 & 0.28 \\
1103P & 0.38 & 3.30 & 0.19 & 1.42 & 5.36 & 0.31 \\
3309C & 0.42 & 3.40 & 0.01 & 1.35 & 4.83 & 0.29 \\
L.S.D. & 0.14 & 0.52 & 0.06 & 0.32 & N.S. & N.S. \\
P<0.01 & & & & & &
\end{tabular}

R.Bb.N: relative bud burst number, G.R.: growth rate after bud burst, G.R.V.: growth rate at veraison, P.W.: pruning weight, M.I.L.: mean internode length of the first 10 internodes, R.L.N.: relative lateral number. L.S.D.: least significant differences. N.S.: no significant differences. 


\subsection{Correlation between growth parameters and cytokinins}

Although the cytokinin compounds were measured in xylem sap collected within $24 \mathrm{~h}$ of shoot cutting, the export of cytokinins were inter-correlated to a high degree of significance with most growth parameters. Cytokinins were positively correlated with the relative bud burst number $\left(\mathrm{r}^{2}=0.659, \mathrm{P}<0.01\right)$, elongation rate after bud burst $\left(\mathrm{r}^{2}=0.725, \mathrm{P}<0.001\right)$ and the elongation rate at the veraison stage $\left(\mathrm{r}^{2}=0.811, \mathrm{P}<0.001\right)$ of the shoots, at the time which elongation growth ceased.

The pruning weight also showed a positive, though less marked correlation. No significant correlation was found for yield per vine, berry composition and mean length of the first ten internodes.

\section{Discussion}

There are several reports in the literature which indicate that the root system of plants is the main site of cytokinin-like compound synthesis [37], and that transportation of cytokinins to the shoots of plants occurs in xylem sap [14, 42]. As shown in Figure 1 results obtained in this study indicated that cytokinin content of xylem exudates is strongly influencd by the rootstock variety. Differences found among the rootstock varieties used in the present study could probably be due to the genetic factors affecting the root system. 110R and 99R rootstocks which showed increased levels in sap cytokinins are Berlandieri X Rupestris crossings and have been classified as rootstocks of high vigour [15]. It can be seen in Table II, that the rootstock variety markedly influenced the growth pattern of the scion. Williams and Smith [45], reported that genetic factors considerably determine the density of thin roots (less than $2 \mathrm{~mm}$ in diameter) in the soil, while edaphic conditions determine the distribution of roots in the soil profile. Differences found among rootstock varieties may be due to different root density in superficial layers of the soil which warmed up rapidly in early spring [45].
Morano and Kliewer in a field experiment [24] found significant differences in root density among different rootstocks. They also reported a significant rootstock-soil depth interaction. It is possible that differences in exudate cytokinins among the rootstock varieties resulted because of the different size and density of the root system particularly in superficial parts of the soil.

Comparing the xylem exudate volume with the cytokinin content, it was found that rootstocks with high levels of exudated cytokinins produced also increased volume of xylem exudate. The apparent relationship between exudate volume and cytokinin content may confirm a possible relationship between cytokinin and nutrient elements. Environmental factors have been shown to greatly affect exudate volume and exudate solute concentrations. Andersen and Brodbeck [4] reported that increase in preconditioning temperatures promoted an increased solute concentration. They also reported that increases in solute concentrations were associated with increases in exudate flux volume. In our experiment exudate samples were collected at the same time thus the influence of the temperature had a similar effect on the different rootstocks. Thus differences observed among the rootstocks may be due rather to different root density in superficial layers of the soil.

There is no extensive literature about the cytokinins-nutrient element relationships but several reports suggest that cytokinins are related to nitrogen supply. Sattelmacher and Marschner [36], reported that elevated concentrations of exudatecytokinins was associated with high levels of total nitrogen content. They also suggested that with continuous $\mathrm{N}$ supply, exudate rate remained constant throught a 6-day period but the cytokinin in exudate increased considerably. Singh et al. [38], reported that nitrogen supply, principally $\mathrm{NH}^{+}$ions, exerts not only a considerable influence on plant cytokinin levels, but also a retardation of leaf senescence. The elevated cytokinin association with high nitrogen content may be due to both activation of basic purine biosynthesis and inhibition of purine catabolism. These mechanisms could increase the availability of the cytokinin precursor aminopurine [44]. 
In the present study the xylem exudate was used to evaluate the relationship between cytokinin and nutrient content in the various rootstocks. It has been reported that short time $(0.5-1 \mathrm{~h} / \mathrm{m})$ is required for the fluid in the root xylem to travel the path to the pruned canes [6]. In addition these authors reported that the xylem exudate appears to change little qualitatevely or quantitatively above the roots, since chemical profile of fluid collected $5 \mathrm{~cm}$ above the soil was similar to that collected from cut spurs on cordon trained vines. So the nutrient concentration of the xylem exudate may be more closed to the nutrient absorption rootstock ability.

Regression analysis indicated a very low correlation coefficient between cytokinin and nutrient levels in xylem exudate, as well as in leaf blades and petioles for most of the nutrients, except for total nitrogen which was strongly correlated to the cytokinins. However, when Hierarchical Cluster analysis was performed using 28 initial variables concerning the exudate-nutrient elements, the exudate-cytokinins and the leaf nutrient elements, it was detected that the rootstocks with high levels of cytokinins $(420 \mathrm{~A}, 99 \mathrm{R}$ and $110 \mathrm{R})$ were grouped in the same cluster. The rootstocks with intermediate (41B and $8 \mathrm{~B}$ ) and intermediate or low levels of cytokinins $(5 \mathrm{BB}, 31 \mathrm{R}$, and 3309C) were also included in two other clusters, respectively. Cluster analysis showed that rootstocks of the same group have a close behaviour in nutrient uptake. It was detected that rootstocks with high levels of exudate cytokinins (420A, 110R, 1103P and 99R) had also high levels of exudate- $\mathrm{N}$, blade-N, blade- $\mathrm{Zn}$, blade and petiole- $\mathrm{Cu}$ and exudate $\mathrm{Ca}$. It has been reported that rootstocks with different genetic parentage showed differences in scion nutrient status, growth and yield. Grant and Matthews [17] reported that different rootstocks absorb different amounts of $\mathrm{P}$ and that shoot and leaf growth resulted from a different $\mathrm{P}$ uptake. They also demonstrated that under sufficient $P$ supply, vines grafted on $110 \mathrm{R}$ had higher petiole $\mathrm{P}$ concentrations than vines grafted on other rootstocks (Freedom, AXR\#1, Lot).

The initial hypothesis examined in the present study, that the xylem sap cytokinin levels are related to nutrient uptake, has not been confirmed for all the nutrients. It is well known that total amounts and concentrations of the plant nutrient levels are governed by the needs of the plant growth and development and that mineral uptake of the roots, as well as nutrient translocation and compartmentalization may be involved in the manifestation of varietal differences $[12,24]$. As is seems in Table I, the close behaviour of the rootstocks in the same group may be attributed rather to the nutrient uptake in veraison stage. Thus the results could have been improved if analysis would have been performed on xylem exudates from leaf petiole at this stage with a Scholander pressure chamber.

The remarkable differences in exudate cytokinins among the rootstocks are clearly correlated with the growth parameters measured on the canes. The rootstocks with high levels of cytokinin concentrations also had high relative bud burst number. $110 \mathrm{R}$ rootstock had the highest relative bud burst number, followed by the 420A and 99R. $110 \mathrm{R}$ rootstock was classified as high vigour, causing a high bud burst and more active shoot growth. According to Weaver [43] the grapevine requires cytokinin for bud-burst, coming from the roots via xylem sap. It has also been reported that bursting buds contain considerable amounts of cytokinins and that high levels of these substances coincide with the swelling of buds that precedes bud break [31].

There are several reports of cytokinins reaching their highest concentration just before bud burst in spring and declining to low concentrations later in season $[2,18]$. Therefore concentration, obtained just before bud burst, depict more accurately the amounts eventually available to the buds at this stage.

Rootstock also had a considerable effect on growth rate after bud burst. Many workers have concluded that the size of the root system is an important factor in determining the shoot growth $[11,21]$. A close positive dependence has been reported between the cytokinin concentration in the roots and the shoots, considerably affecting the shoot growth [23]. Besides that, Richards and Rowe [33], supported that the controlling influence of the root on the growth of the shoot is mediated 
by its cytokinin production. A positive relationship has also been reported between endogenous cytokinins and delayed senescence [29]. Although a positive correlation between cytokinins and growth rate was found in the present study there is an important reason for a careful interpretation of this relationship, because xylem exudate also contains gibberillin-like substances which may be implicated by the effect of cytokinins on shoot elongation [40].

There were no remarkable differences in mean internode length of the ten first internodes, but we observed that in most cases the rootstocks with high growth rate was also longer in the forth and fifth internodes. Differences in elongation rate at this stage can also be attributed to more internodes of the shoots.

Rootstocks with increased cytokinin concentrations also had a later shoot growth inhibition. Differences found in shoot growth rate before veraison are of particular interest since the growths ceasing occuring at this stage influences the progress of fruit maturity. For a satisfactory or early fruit maturity the competition for assimilates between the vegetative parts and fruits may be eliminated earlier by shoot cession.

Shoot growth cession was earlier when the Thompson seedless variety was grafted to 3309C. It has been proposed that the root cytokinins play an important role in shoot metabolism and that shoot growth may be closely regulated by cytokinins and other hormones [10, 27]. Moreover it is known that nitrogen deficiency not only decreases cytokinin activity in the shoots and simultaneously accelarates senescence [39], but also increases ABA content [16]. Therefore, bud burst and growth of developing shoots may be associated with a different supply of cytokinins from the roots to the shoots, as a result of the varietal differences in the root activity. Concerning the interaction between cytokinins, mineral nutrition and growth, it is likely that cytokinins affect vine growth directly rather than through increased mineral uptake; Kuiper [22] demonstrated that dilution of mineral nutrients in the medium results in a rapid cessation of growth which can be reinitiated by cytokinin treatment and that mineral nutrient concentrations, besides their nutritive function, can also act as signals which affect phytohormonal balace.

In this study the highest yield was measured on vines grafted onto 41B. Vines grafted on 3309C and 1103P, had a low yield per vine and the highest soluble solids.

It has long been known that an increased supply of cytokinins may be responsible for enhanced reproductive development $[23,41]$, because cytokinin plays a major role in reproductive tissue formation but in this study no remarkable differences were observed in the number of clusters among the rootstocks (data not shown).

\section{Conclusion}

We conclude that shoot growth is dependent on the rootstock variety. The rootstock variety affects considerably the relative bud burst number, the shoot elongation and the yields of the grapevine. The cytokinin content of xylem exudate delivered from the roots, before bud burst, varies significantly between rootstock varieties and is closely related to the relative bud burst number, and the elongation rate of the shoots measured at the begining of growth and before the veraison stage. Elevated amounts of cytokinins are closely related to the total nitrogen of xylem exudate and leaf petioles. Concerning the differences in mineral uptake of the rootstocks, more work is necessary, particularly cytokinin and nutrient analysis at various stages, to demonstrate a link between cytokinin synthesis and mineral uptake, as well as the influence of the root system patterns on both cytokinin content and nutrient uptake.

\section{References}

[1] Abdelazziz E.,Williams L.E., The influence of rootstock on leaf water potential yield, and berry composition of Ruby Seedless grapevine, Am. J. Enol. Vitic. 46 (1995) 559-563. 
[2] Alvim R., Hewett E.W., Saunders P.F., Seasonal variation in the hormone content of willow. I. Changes in abscisic acid content and cytokinin activity in the xylem sap, Plant Physiol. 57 (1976) 474-476.

[3] Amzallag G.N., Lerner H.R., Poljakoff-Mayber A., Interaction between mineral nutrients, cytokinin and gibberellic acid during growth of Sorgum at high $\mathrm{NaCl}$ salinity, J. Exp. Bot. 43 (1992) 81-87.

[4] Andersen P.C., Brodbeck B.V., Temperature and temperature preconditioning on flux and chemical composition of xylem exudate from Muscadine grapevines, J. Am. Soc. Hortic. Sci. 114 (1989) 440-444.

[5] Andersen P.C., Brodbeck B.V., Chemical composition of xylem exudate from bleeding spurs of Vitis rotundifolia and Vitis Hybrid Suwannee in relation to pruning date, Am. J. Enol. Vitic. 40 (1989) 155-169.

[6] Andersen P.C., Brodbeck B.V., Diurnal and temporal changes in the chemical profil of xylem exudate from Vitis rotundifolia, Physiol. Plant. 75 (1989) 63-70.

[7] Badenochjones J., Parker C.S., Letham D.S., Singh S., Effect of Cytokinins supplied via the xylem at multiples of endogenous concentrations on transpiration and senescence in derooted seedlings of Oat and Wheat, Plant Cell Environ. 19 (1996) 504-516.

[8] Biddington N.L.,Thomas T.H., Influence of different cytokinins on the respiration and senescence of excised oak leaves, Physiol. Plant. 42 (1978) 369-374.

[9] Bollard E.G., Transport in xylem, Annu. Rev. Plant Physiol. 11 (1960) 141-166.

[10] Burrows W.J., Carr D.J., Effects of floodings the root system of sun flower plants on the cytokinin content in the xylem sap, Physiol. Plant. 22 (1969) 1105-1112.

[11] Buttrose M.S., Mullins M.G., Proportional reduction in shoot growth of grapevines with root system maintained at constant relative volumes by repeated pruning, Aust. J. Biol. Sci. 21 (1968) 1095-1101.

[12] Clarkson D.T., Lüttge U., Mineral nutrition: vacuoles and tonoplasts, Progr. Bot. 46 (1984) 56-67.

[13] Doumas P., Zaerr J.B., Seasonal changes in levels of cytokinin-like compounds from Duglas-fir xylem extudate, Tree Physiol. 4 (1988) 1-8.

[14] Fletcher R.A., Mc Gullagh D., Cytokinininduced Chlorophyll formation in Cucumber cotyledons, Planta 101 (1971) 88-90.

[15] Galet P., Cépages et Vignobles de France. Tome I. Les Vignes Américaines, Imprimerie Déhan, Montpellier, 1988.
[16] Goldbach E., Goldbach H., Wagner H., Michael G., Influence of N-deficiency on the ABA content of sunflower plants, Physiol. Plant. 34 (1975) 138-140.

[17] Grant S.R., Matthews M.A., The influence of phosphorus availability and rootstock on root system characteristics, phosphorus uptake, phosphorus partitioning, and growth efficiency, Am. J. Enol. Vitic. 47 (1996) 403-409.

[18] Hewett E.W., Wareing P.F., Cytokinins in Populus $x$ robusta: changes during chilling and bud burst, Physiol. Plant. 28 (1973) 393-399.

[19] Jackson M.L., Soil chemical analysis, Constable and Co Ltd, London, 1960.

[20] Kliewer W.M., Influence of environment on metabolism of organic acids and carbohydrates in Vitis vinifera L. Temperature, Plant Physiol. 39 (1964) 869-880.

[21] Kliewer W.M., Fuller R.D., Effect of time and severity of defoliation on growth of roots, trunk and shoots of "Thompson seedless" grapevines, Am. J. Enol. Vitic. 24 (1973) 59-64.

[22] Kuiper D., Growth responces of Platango major ssp. pleiosperma (Pilger) to changes in mineral supply: Evidence for regulation by cytokinins, Plant Physiol. 87 (1988) 555-557.

[23] Lilov D., Andonova T., Cytokinins, growth, flower and fruit formation in Vitis vinifera, Vitis 15 (1976) 160-170.

[24] Marchner H., Mineral nutrition of higher plants, 2nd ed., Academic Press, London, 1995.

[25] Mercier H., Kerbauy G.B., Sotta B., Miginiac E., Effects of $\mathrm{NO}_{3}^{-}, \mathrm{NH}_{4}^{+}$and urea nutrition on endogenous levels of IAA and four cytokinins in two epiphytic bromeliads, Plant Cell Environ. 20 (1997) 387-392.

[26] Morano L., Kliewer W.M., Root distribution of three grapevine rootstocks grafted to Cabernet sauvignon grown on very gravelly clay loam soil in Oakville, California, Am. J. Enol. Vitic. 45 (1994) 345-348.

[27] Mullins M.G., Morphogenetic effect of roots and some synthetic cytokinins in Vitis vinifera, J. Exp. Bot. 18 (1967) 206-214.

[28] Nitsch J.W., Nitsch C., Présence de phytokinines et autres substances de croissance dans la seve d'Acer saccharum et de Vitis vinifera, Planta 74 (1965) 250-262.

[29] Nooden L.D., Singh S., Letham D.S., Correlation of xylem sap cytokinin levels with monocarpic senescence in soybeam, Plant Physiol. 93 (1990) 33-39. 
[30] Ough S.C., Cook J.A., Lider L.A., Rootstockscion interaction concerning wine making. II. Wine compositional and sensory changes attributed to rootstock and fertilizer level differences, Am. J. Enol. Vitic. 19 (1968) 254-265.

[31] Qamaruddin M., Dormling I., Eliasson L., Increases in cytokinin levels in Scots pine in relation to chilling and bud burst, Physiol. Plant. 79 (1990) 236-241.

[32] Pirstley J.H., Wormall A., On the solutes exuded by root pressure from vines, New Phytol. 24 (1925) 24-38.

[33] Richards D., Rowe R.N., Root-shoot interactions in peach: the function of the root, Ann. Bot. 41(1977) 1211-1216.

[34] Roumpelakis-Angelakis K.A., Kliewer W.M., The composition of bleeding sap from Thompson Seedless grapevines as affected by nitrogen fertilization, Am. J. Enol. Vitic. 30 (1979) 14-18.

[35] Sabater B., Rodriguez M.T., Control of chlorophyll degradation in detached leaves of barley and oat through effect of kinetin on chlorophyllase levels, Physiol. Plant. 43 (1978) 274-276.

[36] Sattelmacher B., Marschner H., Relation between nitrogen, cytokinin activity and tuberization in Solanum tuberosum, Plant Physiol. 44 (1978) 65-68.

[37] Short K.C., Torrey J.G., Cytokinin in seedling roots of pea, Plant Physiol. 49 (1972) 155-160.

[38] Singh S., Letham D.S., Zhang X., Palni L.M.S., cytokinin biochemistry in relation to leaf senescence VI. Effect of nitrogenous nutrients on cytokinin levels and senescence of tobacco leaves, Physiol. Plant. 84 (1992) 262-268.

[39] Sitton D., Itai A., Kende H., Decreased cytokinin production in roots as a factor in shoot senescence, Planta 73 (1967) 296-300.

[40] Skene K.G.M., Gibberellin-like substances in root exudate of Vitis vinifera, Planta 74 (1967) 250-262.

[41] Smikiklas K.D., Below F.E., Role of cytokinin in enhanced productivity of maize supplied with $\mathrm{NH}_{4}^{+}$ and $\mathrm{NO}_{3}^{-}$, Plant and Soil 142 (1992) 307-313.

[42] Tromp J., Ovaa J.C., Seasonal changes in the cytokinin composition of xylem sap of apple, J. Physiol. Plant. 136 (1990) 606-610.

[43] Weaver R.J., Use of Kinine in breaking rest in buds of Vitis vinifera, Nature 198 (1963) 207-208.

[44] Weissman G.S., Influence of ammonium and nitrate nutrition on the pyridine and adenine nucleotides of soybean and sunflower, Plant Physiol. (1972) 142-145.

[45] Williams L.E., Smith R.J., The effect of rootstock on the partitioning of dry weight, nitrogen and potassium and root distribution of Cabernet sauvignon grapevines, Am. J. Enol. Vitic. 42 (1991) 118-122.

[46] Wormall A., The constituents of the sap of the vine (Vitis vinifera L.), Biochem. J. 18 (1924) 11876-12020.

[47] Zelleke A., Kliewer W.M., Factors affecting the qualitative and quantitative levels of cytokinins in xylem sap of grapevines, Vitis 20 (1981) 93-104. 